\title{
CHAROPHYTES (CHARACEAE, CHAROPHYTA) OF THE PUSZCZA ZIELONKA LANDSCAPE PARK IN POLAND: RESPONSE TO THE PROTECTION AND STATE OF CATCHMENT AREAS OF THE WATER BODIES
}

\author{
Daniel Lisek, Piotr Fonfara, Maciej GąbKa
}

\begin{abstract}
D. Lisek, P. Fonfara, M. Gąbka, Department of Hydrobiology, Institute of Environmental Biology, Faculty of Biology, Adam Mickiewicz University, Umultowska 89, 61-614 Poznań, Poland, e-mail: daniel.lisek@amu.edu.pl
\end{abstract}

(Received: October 19, 2018. Accepted: November 12, 2018)

\begin{abstract}
This paper presents localities of charophytes in the Puszcza Zielonka Landscape Park (Wielkopolska, Poland). In this area, 16 species of stoneworts occur, constituting $47 \%$ of national species from this group. The following are the most frequent species: Chara intermedia, C. tomentosa, C. virgata and Nitellopsis obtusa. Four critically endangered species in Poland (Nitella tenuissima, N. capillaris, N. gracilis and Chara tenuispina) were also recorded. Our research has demonstrated: (1) considerable diversity of charophytes on a relatively small area situated in the vicinity of a large urban centre of Poznań, (2) major importance of protected areas such as nature reserves, landscape parks, or Natura 2000 areas etc. for the preservation of charophyta lake habitats, and (3) the significance of the forms of land use in the catchment areas, where forest vegetation or less dense presence of trees and shrubs prevents eutrophication of the water bodies and thus contributes to the protection of the stonewort species occurring there.
\end{abstract}

KEY words: Characeae, Chara, Nitella, Chara intermedia, lake, distribution, threatened and rare charophytes, catchment areas

\section{INTRODUCTION}

Presence of charophytes is a good long-term indicator of quality in mesotrophic lakes, in particular those included in the habitat Natura 2000 H3140: Hard oligo-mesotrophic waters with benthic vegetation of Chara spp. (e.g. Kufel \& Kufel 2002, Piotrowicz 2004, GĄBKA et al. 2015). The indispensable element for the protection of stoneworts is sustaining optimal habitat conditions for particular species in standing water bodies and watercourses. It is therefore necessary to maintain or restore appropriate management practices in the catchment area or leave an adequate buffer zone to prevent influx of substances which have an adverse impact on the habitats, biogens in the main (VAN DEN Berg 1999, Hutorowicz \& DziedZic 2008, GąbKa \& Owsianny 2012, Grzybowski 2014, GĄBKA et al. 2015). Hence there is a need for inventory surveys, assessments of the state of preservation, monitoring of sites, habitats and populations. Furthermore, databases relating to charophyta sites should be kept up to date and made accessible to ensure effective management and protection of lakes and other water bodies.

Twenty one of the 34 stonewort species found in Poland are subject to strict protection (URBANIAK \& GĄBKA 2014), while nine species are covered by the partial protection scheme (Regulation... 2014). Also, stoneworts are characteristically encountered in the habitat designated as: Hard oligo-mesotrophic waters with benthic vegetation of Chara spp., protected as part of the Natura 2000 (Council Directive... 1992, Interpretation MANUAL... 2007, GąbKa et al. 2015). Moreover, they are phytoindicators of low trophic level in lakes and water bodies, and display high susceptibility to deterioration of water quality 
and adverse changes in the catchment areas of water bodies in which they occur (Kufel \& Kufel 2002, Petechaty 2006). Therefore comprehensive survey of their distribution in the protected areas is vital, especially in terms of protection from anthropogenic pressure in the vicinity of large cities such as Poznań and their conurbations. Such information is absolutely necessary for appropriate protection planning and population management of the species in question. The knowledge can also be taken advantage of when managing protected areas where they occur.

The aim of this work was to present the distribution of charophytes in the Zielonka Forest Landscape Park, which also incorporates a Special Area of Conservation "Uroczyska Puszczy Zielonki", (PLH300058) established as part of Natura 2000. Attempts have been made to identify and determine the impact of the management within the catchment area and direct drainage zones on the species composition of charophyta in lakes, ponds, former peat pits, marshlands, and peat bogs.

\section{MATERIAL AND METHODS}

The research was conducted within the boundaries of the Zielonka Forest Landscape Park and its buffer zone, whose total surface area amounts to 21791.3 ha. The inventoried area lies across the administrative districts of Czerwonak, Murowana Goślina, Skoki, Kiszkowo and Pobiedziska (Fig. 1), whereas in physical-geographical terms it belongs to the macroregion known as the Greater Polish Lake District (KonDRACKi 2000). The list of sites was compiled based on available literature and herbaria collected at the Department of Hydrobiology, Faculty of Biology, Adam Mickiewicz University in Poznań, as well as surveys in the field conducted in 2017-2018. Data for the period prior to 1944 was obtained through analysis of the herbarium by I. Dąmbska; the same source, as well as Dąmbska's publication (DĄMBSKA $1952,1966)$ served to derive data for 1945-1979. Distribution of the charophyta sites in 1980-1999 was developed based on the herbarium materials collected by M. Gąbka and pertinent publications. Further information concerning habitat distribution in 2000-2018 was communicated in e.g. GĄBKA \& KoKociński (2001), PeŁechaty \& GąbKa (2003), GąbKa (2007, 2009), GąbKa et al. (2007) and Urbaniak et al. (2008). Locations where research was carried out included lakes, marshland, peat bogs, as well as water bodies of anthropological origin, i.e. fish-breeding ponds, former gravel and peat pits. The designations of the lakes are adopted as provided in CHOIŃsKI (2006), while the naming of stoneworts follows ALGAEBASE (http://www.algaebase.org).

The boundaries of the direct drainage zones for each site were determined using GIS instruments, following the analysis of the DTM on sheets corresponding to 1:10 000 maps (mean error $0.8-2 \mathrm{~m}$ ) obtained from the Centre for Geodetic and Cartographic Documentation. The use of land in the direct drainage zones was determined using data from Corine Land Cover (2012).

\section{RESULTS}

Nearly 140 water bodies are to be found in the studied area; approximately 25\% (34 sites) of those are populated by stoneworts. In total, 16 species have been identified (Chara - 11 species, 4 species from the genus Nitella and 1 from the genus Nitellopsis; Table 1). The following main types of habitats have

Table 1. Occurrence of charophyta species in particular types of habitats: (1) shallow humotrophic lakes (depth < $3 \mathrm{~m}$ ),

(2) medium-depth lakes 5-12 m, (3) ponds, peat ponds, and marshlands, (4) depressions in transitional peat bogs

\begin{tabular}{|c|c|c|c|c|c|}
\hline Species & Threats categories in Poland & 1 & 2 & 3 & 4 \\
\hline Chara aspera C.L. Willdenow $1809^{* *}$ & EN & & 1 & & \\
\hline Chara contraria A. Braun ex Kützing $1845^{* *}$ & VU & & 3 & 1 & \\
\hline Chara filiformis $\mathrm{H}$. Hertzsch $1855^{* *}$ & $\mathrm{EN}$ & & 1 & & \\
\hline Chara globularis Thuiller 1799 & UE & 3 & 5 & 2 & \\
\hline Chara hispida Linnaeus $1753^{*}$ & UE & 3 & 2 & 6 & 1 \\
\hline Chara intermedia A. Braun in Braun, Rabenhorst \& Stizenberger 1859 * & VU & 6 & 6 & 5 & 1 \\
\hline Chara polyacantha A. Braun in Braun, Rabenhorst \& Stizenberger 1859 ** & EN & & 2 & & \\
\hline Chara tenuispina A. Braun $1835^{* *}$ & $\mathrm{CR}$ & 1 & & & \\
\hline Chara tomentosa Linnaeus $1753 *$ & VU & 7 & 7 & 3 & 1 \\
\hline Chara virgata Kützing 1834 & UE & 4 & 6 & 3 & 1 \\
\hline Chara vulgaris Linnaeus 1753 & UE & 1 & & 3 & \\
\hline Nitella capillaris (A.J. Krocker) J. Groves \& G.R. Bullock-Webster $1920^{* *}$ & $\mathrm{CR}$ & & 1 & & \\
\hline Nitella gracilis (J.E. Smith) C. Agardh $1824^{* *}$ & $\mathrm{CR}$ & & & 1 & \\
\hline Nitella syncarpa (J.L. Thuillier) Kützing $1845^{* *}$ & EN & & & & 1 \\
\hline Nitella tenuissima (Desvaux) Kützing $1843^{* *}$ & CR & & & & 1 \\
\hline Nitellopsis obtusa (N.A. Desvaux) J. Groves 1919 * & VU & 6 & 4 & 1 & \\
\hline
\end{tabular}

Threats categories in Poland (URBANIAK \& GĄBKA 2014: CR - critically endangered species, rare, EN - endangered species, VU - vulnerable species, UE - common species, unendangered); ${ }^{*}$ - strict protected species, ${ }^{*}$ - partial protection in Poland. 


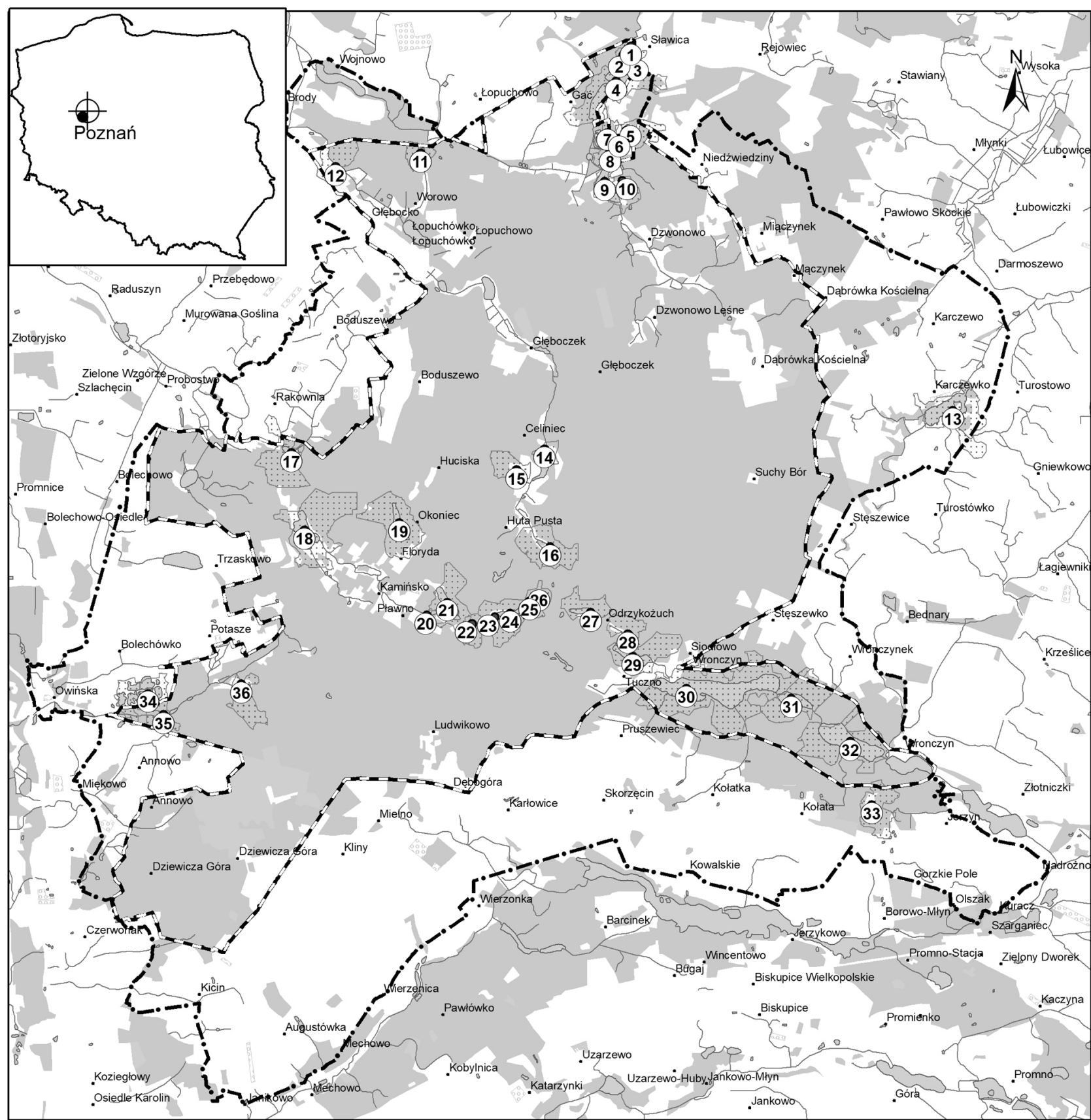

boundaries of the Puszcza Zielonka Landscape Park

i._.i. buffer zone of the Puszcza Zielonka Landscape Park catchment area

1 Peatland exploatation pond 2 Garnek Lake

3 Peatland exploatation pond near Gackie Lake

4 Gackie Lake

5 Borówie Lake

6 Pond near Borówie Lake

7 Peatland exploatation pond near

Borówie Lake

8 Książe Lake

9 Dzwonowskie Lake

10 Peatland exploatation pond near

Dzwonowskie Lake

11 Dobra Lake

12 Pond in Głębocko
13 Turostowskie Lake

14 Pond in the arboretum in Zielonka

15 Peatland exploataatation pond in Zielonka

16 Trojanka spring pool

17 Karpnik Lake

18 Kamińsko Lake

19 Miejskie Lake

20 Peatland exploatation pond near Pławno

21 Pławno Lake

22 Kociołek Lake

23 Peatland near SW shore of the Czarne Duże Lake

24 Czarne Duże Lake

25 Peatland beetwen Czarne Duże \& Czarne Małe lakes

26 Czarne Małe Lake

27 Peatland near east shore of the Modre Lake
(10) sites inhabited by stoneworts

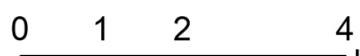

28 Pool near the Tuczno Lake

29 Tuczno Lake

30 Kołatkowskie Lake

31 Stęszewskie Lake

32 Wronczyńskie Duże Lake

33 Pool near the. "letnisko Zielona Polana" in Kołata 34 Gravel pit in Owińska

35 Ponds on the Owńska Struga

36 Waterhole near Owińska Struga

Fig. 1. Distribution of lakes and other water bodies with charophytes from Puszcza Zielonka Landscape Park 


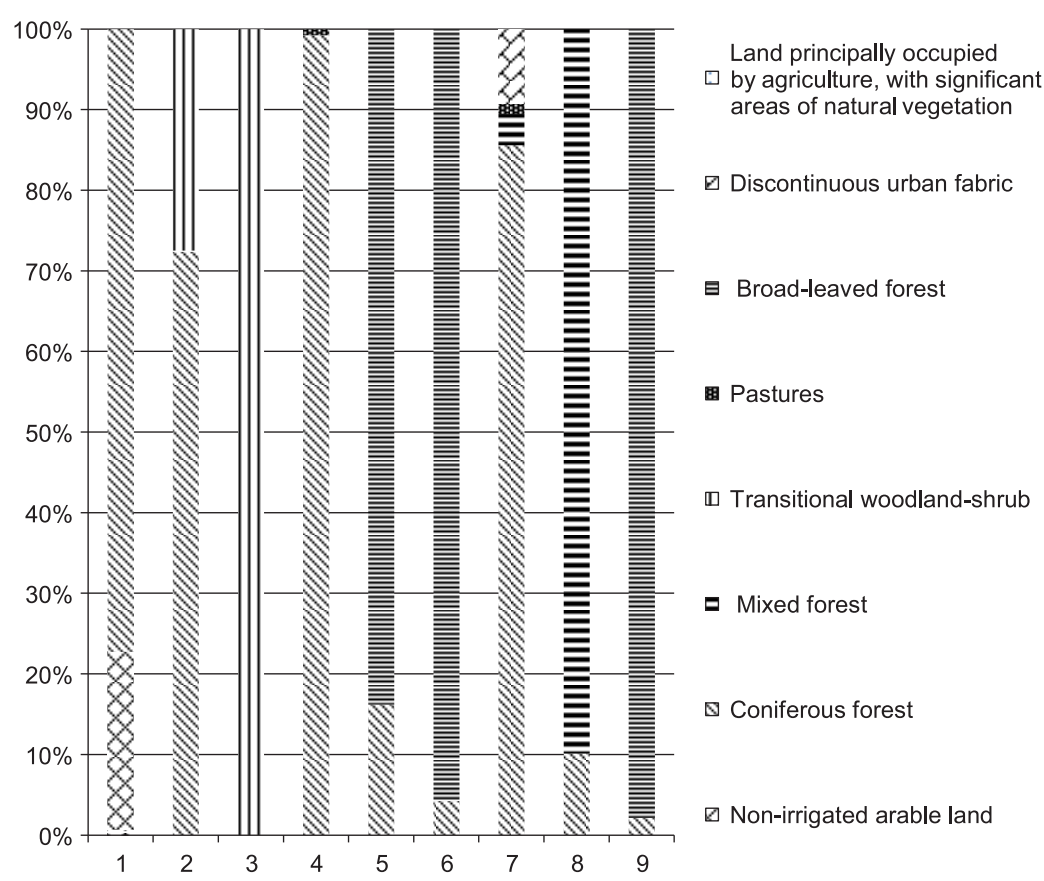

Fig. 2. Land use in direct drainage areas of the shallow humotrophic lakes (depth $<3 \mathrm{~m}$ ). Lakes: 1) Borówie, 2) Czarne Duże, 3) Czarne Małe, 4) Dobra, 5) Dzwonowskie, 6) Garnek, 7) Karpnik, 8) Kociołek, 9) Książe

been distinguished among the analysed sites inhabited by stoneworts: 1) shallow humotrophic lakes (less than $3 \mathrm{~m}$ deep), 2) medium-depth lakes 5-12 m, 3) ponds, peat ponds and marshland, 4) depressions in transitional peat bogs. The greatest number of species was determined in shallow lakes (less than $3 \mathrm{~m}$ deep), and the most numerously found species were Chara intermedia, C. tomentosa and C. virgata (Table 1).

Forests - for the most part deciduous and coniferous - predominate in the direct drainage zones of the shallow humotrophic lakes. However, mixed forests are prevalent in the catchment area of the Kociołek

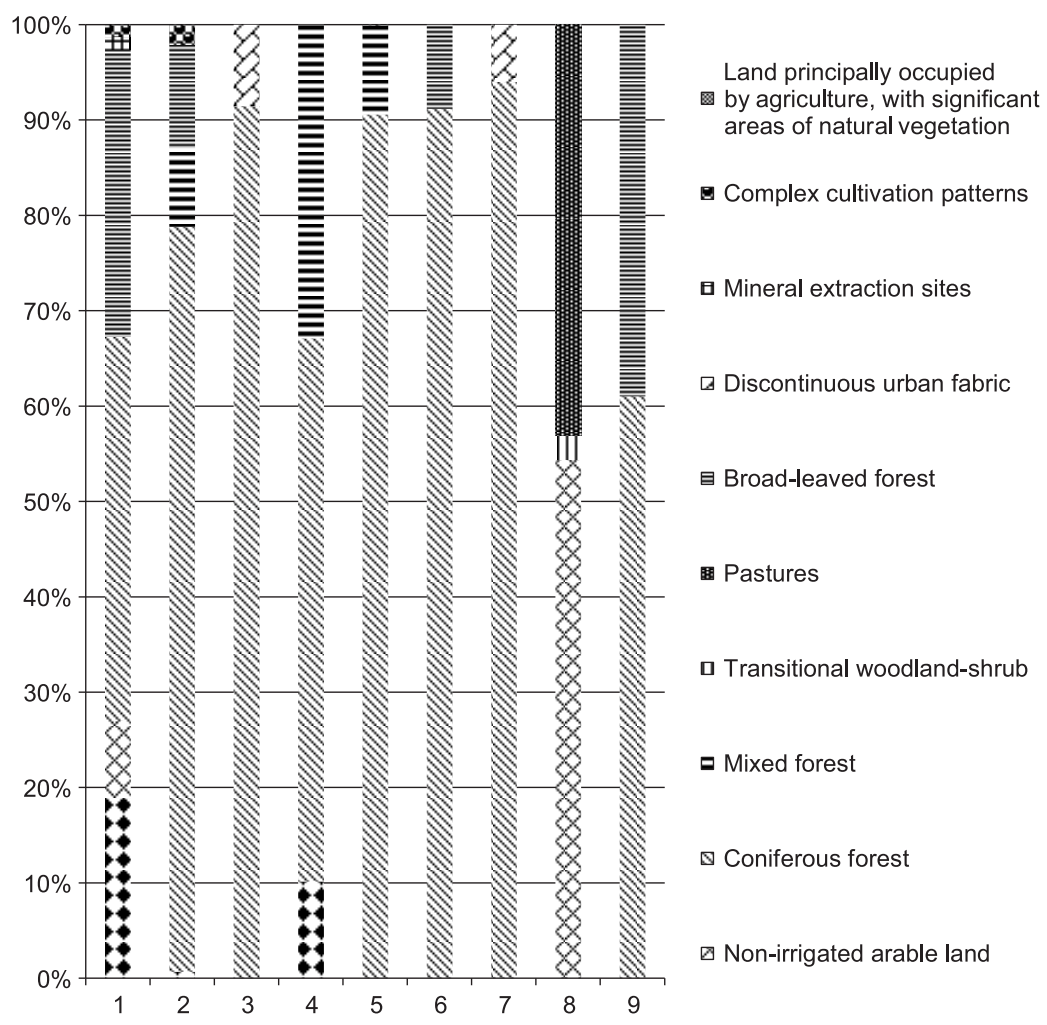

Fig. 3. Land use in direct drainage areas of the medium-depth lakes. Lakes: 1) Gackie, 2) Kamińsko, 3) Kołatkowskie, 4) Miejskie, 5) Pławno, 6) Stęszewskie, 7) Tuczno, 8) Turostowskie, 9) Wronczyńskie Duże 
Lake whereas the entire catchment of the Czarne Małe Lake is covered by forests and shrubs in a state of transition. Sports and leisure grounds account for a marginal part of the catchment of the Borówie Lake $(0.7 \%)$, while loose development of the urban type is seen in $9.0 \%$ of the catchment surface of the Karpnik Lake. Arable land is found only in the catchment of the Borówie Lake, making up $22 \%$ of its area (Fig. 2).

Catchment areas of the medium-depth lakes is more diversified in terms of land use, as sports and leisure grounds are seen there more frequently. Nevertheless, forests - chiefly coniferous ones - are their predominant feature, with the exception of the Turostowskie Lake, which is surrounded by arable land (54.4\%), as well as meadows and pastures (43.1\%). Loose residential development is to be found only in the catchment area of the lakes Kołatkowskie (8.5\%) and Tuczno (6.0\%; Fig. 3).

Ponds, peat ponds and marshlands were the most numerous group of water bodies inhabited by stoneworts. Their catchment areas are smaller than those of lakes, but they are largely covered by forests as well. Again, the coniferous type predominates, followed by the deciduous tree stand. Here, the exceptions include the peat pond in the vicinity of Gackie Lake, where $83.5 \%$ of the catchment area is taken up by a complex system of cultivation and allotments, the pond in the arboretum in Zielonka whose catchment comprises $80.5 \%$ of agricultural land with a substantial share of natural vegetation, as well as the pond near

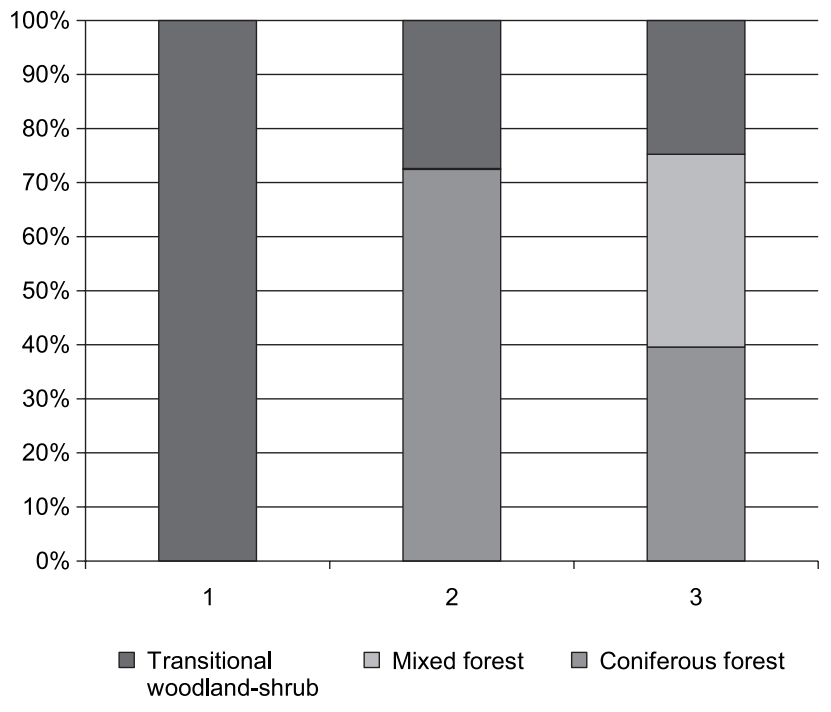

Fig. 5. Land use in direct drainage areas of the depressions in transitional peat bogs: 1) peatland beetwen Czarne Duże and Czarne Małe lakes, 2) peatland near SW shore of the Czarne Duże Lake, 3) peatland near east shore of the Modre Lake

the Borówie Lake, where sports and leisure grounds account for $68 \%$ of its catchment area (Fig. 4).

Catchment areas of the depressions in transitional peat bogs were entirely covered by forests $(100 \%$; Fig. 5).

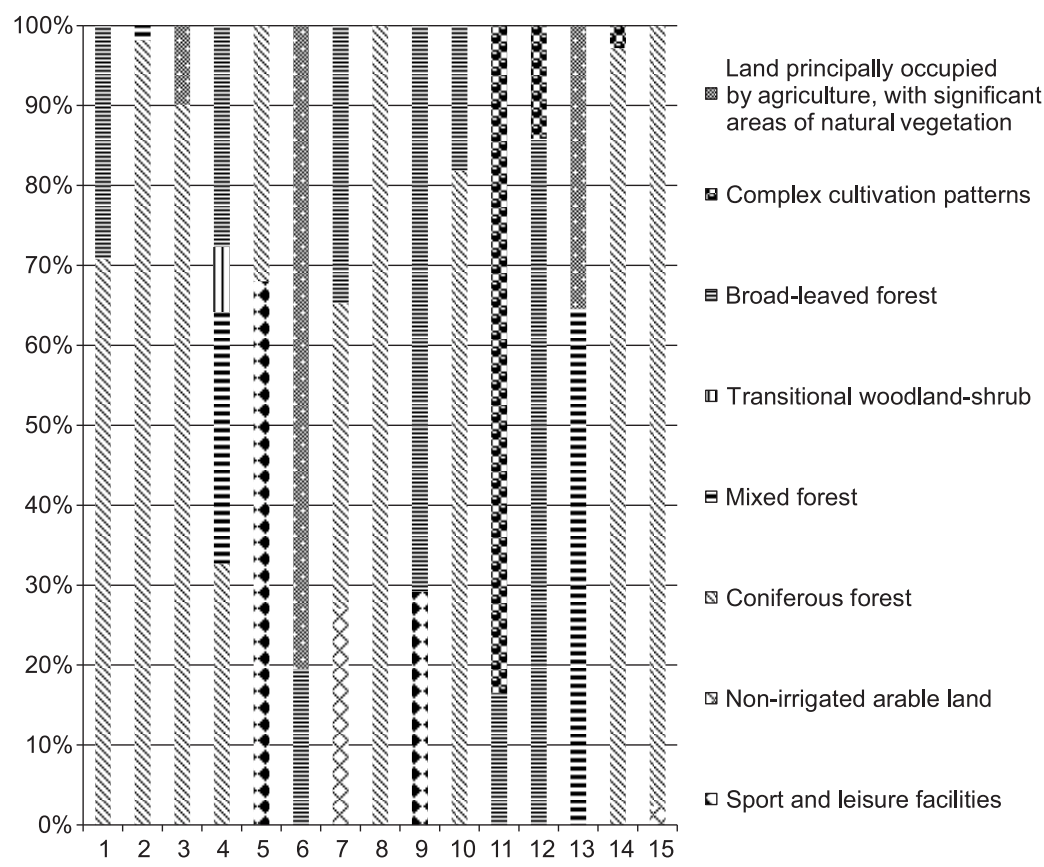

Fig. 4. Land use in direct drainage areas of the ponds, peat ponds and marshlands: 1) waterhole near Owińska Struga, 2) pool near the Tuczno lake, 3) pool near the "letnisko Zielona Polana" in Kołata, 4) Trojanka spring pool, 5) pond near Borówie Lake, 6) pond in the arboretum in Zielonka, 7) pond in Głębocko, 8) ponds on the Owńska Struga, 9) peatland exploitation pond near Borówie Lake, 10) peatland exploitation pond near Dzwonowskie Lake, 11) peatland exploitation pond near Gackie Lake, 12) peatland exploitation pond near Sławica, 13) peatland exploitation pond in Zielonka, 14) peatland exploitation ponds near Pławno, 15) gravel pit in Owińska 


\section{DISCUSSION}

Our research has demonstrated: (1) considerable diversity of stoneworts on a relatively small area situated in the vicinity of a large urban centre, (2) major importance of protected areas such as nature reserves, landscape parks, or Natura 2000 areas etc. for the preservation of charophyta lake habitats, and (3) the significance of the forms of land use in the catchment areas, where forest vegetation or less dense presence of trees and shrubs prevents eutrophication of the water bodies and thus contributes to the protection of the stonewort species occurring there.

The diversity of aquatic habitats, spanning lakes, ponds, peat ponds and marshlands across the Puszcza Zielonka Landscape Park is reflected in the diversity of the charophyta species. As many as 16 species of the macroalga have been determined in the entire studied area, i.e. $47 \%$ of all species found in Poland. Charophytes from the genus Chara constituted the majority with 11 species; four species belonged to the genus Nitella and one to the genus Nitellopsis. Chara intermedia, a stonewort found chiefly in lakes and former peat pits has been determined in the greatest number of sites (19), which makes the entire area an important location where that rare species may be encountered. Chara tomentosa, which came second in terms of the number of inhabited sites (18), has been determined chiefly in lakes, though it occurred in ponds as well (e.g. pond near the Borówie Lake, the pond at Owińska Struga and the peat pond near Sławica). This species displays a relatively broad trophic tolerance (GABKA 2009, URBANIAK \& GĄBKA 2014), whereas it may be noted that the presence of $C$. intermedia was associated with shallow bodies situated in forest surroundings whose waters were coloured by humic substances (shallow humotrophic lakes, GĄBKA et al. 2007).

Based on the analysis of long-term data from literature and herbaria, it follows that most charophyta species have been continuously present in that area for as long as 95 years, and that their populations are characterised by considerable stability. The rarest and critically endangered (CR) species observes in some of the sites included N. tenuissima, N. capillaris, N. gracilis and C. tenuispina; the relatively rare and endangered (EN) C. polyacantha, C. filiformis, C. aspera, and $N$. syncarpa were also determined. However, presence of the extremely rare $N$. capillaris was not confirmed in 2000-2018 at its only site in the studied area, i.e. Pławno Lake, though it should be remembered that the species is highly ephemeral, occurring chiefly in early spring, while its environmental requirements have not been sufficiently explored (URBANIAK \& GĄBKA 2014). The number of sites of $C$. polyacantha has also decreased; previously found in three sites, it has been determined in recent years only in the lakes Kamińsko and Pławno, because the third site (peat pond in Dziewicza Góra) no longer exists: for this reason, the location has not been included in the figure showing the distribution of the charophyta sites. One should also draw attention to the diminishing biodiversity of stonewort flora in the lakes Czarne Małe and Czarne Duże which are parts of the nature reserve "Jezioro Czarne", though it may be noted that the strictly protected and critically endangered (CR) C. tenuispina has indeed been observed recently in the Czarne Duże Lake. Data from literature and field surveys clearly show that the Puszcza Zielonka Landscape Park plays an important role in the protection of the charophyte flora given the substantial species diversity of the macroalgae within its bounds, in spite of the extensive urban pressure and the proximity of a large city (Poznań). This may be attributed to a considerable share of forests and undeveloped areas in the direct drainage zones of the water bodies inhabited by stoneworts.

A great majority of such water bodies in the studied area is surrounded by forest vegetation; alternatively, a certain amount of tree stand and shrubs is to be found in their immediate environs. Those cases where the zone of direct drainage is entirely or almost entirely covered by forest vegetation (>90\%) account for $66 \%$ of all water bodies in which stoneworts occur, while $86 \%$ of all stonewort sites have the majority of their respective drainage areas covered by forest $(>70 \%)$. The rarest and the most valuable species, i.e. $N$. tenuissima, $N$. capillaris and C. tenuispina as well as C. polyacantha, $N$. syncarpa and $N$. gracilis have been determined in those water bodies where the surrounding forest vegetation exceeded $90 \%$. In contrast, where other forms of land use - agriculture, sports and leisure, complex cultivation and allotments - exceeded $45 \%$ of the surface area of the direct drainage zones, the species in such water bodies included e.g. C. hispida, C. tomentosa, C. globularis, C. intermedia and C. vulgaris, in other words species which prefer habitats characterised by a broader trophic spectrum, from meso- to eutrophy (URBANIAK \& GĄBKA 2014). Stoneworts were practically absent in the flow-through lakes along minor watercourses and water bodies adjacent to village complexes and recreational developments. Lakes of that kind were for the most part highly eutrophied due to biogens supplied by the watercourses in their catchment areas. As an example, one could quote the water bodies located in the north-western part of the studied area, along the stream Trojanka.

The above analysis demonstrates a correlation between the form of land use in the immediate surroundings of a water body and the species composition of stoneworts occurring there. Thus, in order to sustain species diversity and ensure continued presence of species which can only tolerate low trophic levels, protection should encompass not only the water body itself but also its entire catchment area, especially the direct drainage zone of the habitat where the 
species occur. This is particularly important in the case of small, shallow bodies, which are considerably more susceptible to degradation than large, deep lakes.

In consequence, if one aims to maintain biodiversity of water bodies under protection - especially those within the nature reserve scheme - their boundaries should be delimited in such a way that they incorporate their catchment areas or at least the immediate drainage zone. As for the management of national parks, landscape parks or Natura 2000 areas, planning documents should draw attention to the threats associated with the transformation of land in the direct catchment area of such water bodies.

\section{REFERENCES}

AlgaeBase. (2018). World-wide electronic publication, National University of Ireland, Galway. http://www.algaebase.org; searched on 15 September 2018.

CHorński A. (2006): Katalog jezior Polski. Wydawnictwo Naukowe UAM, Poznań.

Council Directive 92/43/EEC of 21 May 1992 on the conservation of natural habitats and of wild fauna and flora (Annex I, II).

DĄmbSKa I. (1952): Ramienice okolic Poznania. Acta Societatis Botanicorum Poloniae 21, 3: 335-368.

DĄmBSKA I. (1966): Zbiorowiska ramienic Polski. Prace Komisji Biologicznej Poznańskiego Towarzystwa Przyjaciół Nauk 31, 3: 1-76.

GĄвKA M. (2000): Osobliwości florystyczne rezerwatów „Jezioro Czarne” i „Jezioro Pławno” w Parku Krajobrazowym „Puszcza Zielonka” koło Poznania”. Badania Fizjograficzne nad Polską Zachodnią, Seria Biologia 49: 189-193.

GĄBKA M. (2007): Distribution of Chara tenuispina A. Braun 1835 (Characeae) in Poland. Oceanological and Hydrobiological Studies 36: 241-248.

GĄBKA M. 2009: Charophytes of the Wielkopolska region (NW Poland): distribution, taxonomy and autecology. Bogucki Wydawnictwo Naukowe, Poznań.

GąbKa M., Bociąg K., Chmara R., Jakubas E., Joniak T., Kisiel A., Lisek D., Messyasz B., Pęechaty M., Pęczuza W., Pukacz A., Rekowska E., Rybak M., WiLK-WoźNIAK E. (2015): (3140) Twardowodne oligo- i mezotroficzne zbiorniki z podwodnymi łąkami ramienic (Charetea). In: W. Mróz (ed.). Monitoring siedlisk przyrodniczych. Przewodnik metodyczny. Część 4. Główny Inspektorat Ochrony Środowiska, Biblioteka Monitoringu Środowiska, Warszawa: 120-140.

GĄвкA M., КокосіŃski M. (2001): Jezioro Borówie (Puszcza Zielonka) - ocena hydrobotaniczna W aspekcie antropopresji. Przegląd Przyrodniczy 12, 1-2: 135-146.

GąbKa M., Owsianny P.M. (2012): Problem of protection of the Chara-dominated lakes from the eastern part of the Gnieźnieńskie Lakeland (western Poland) in the conditions of disturbed water regime. In: K. Wołowski, I. Kaczmarska, J.M. Ehrman, A.Z. Wojtal (eds). Current advances in algal taxonomy and its applications: phylogenetic, ecological and applied perspective. W. Szafer Institute of Botany, Polish Academy of Sciences, Kraków: 287-301.

GąbKa M., Owsianny P.M., Burchardt L., SobczyŃSKi T. (2007): Habitat requirements of the Charetum intermediae phytocoenoses in lakes of western Poland. Biologia 62, 6: 657-663.

GrzYBowski M. (2014): Determinants of the diversity of macrophytes in natural lakes affected by land use in the catchment, water chemistry and morphometry lakes. Journal of Elementology 19, 2: 401-422.

Hutorowicz A., Dziedzic J. 2008. Long-term changes in macrophyte vegetation after reduction of fish stock in a shallow lake. Aquatic Botany 88(3): 265-272.

INTERPRETATION MANUAL of European Union Hab itats, EUR 27. (2007). European Commission, DG Environment, Nature and Biodiversity, July 2007.

KondRacki J. (2000): Geografi a regionalna Polski. Wydawnictwo Naukowe PWN, Warszawa.

Kufel L., Kufel I. (2002): Chara beds acting as nutrient sinks in shallow lakes - a review. Aquatic Botany 72: 249-260.

Petechaty M. (2006): Wykorzystanie ramienic w fitoindykacji. Ekologia i Technika 3: 98-102.

Petechaty M., GąbKa M. (2003): Two approaches to lake-naturalness determination - a case study from four mid-forest Polish lakes. Polish Journal of Environmental Studies 12, 4: 607-611.

Piotrowicz R. (2004): 3140 - Twardowodne oligoi mezotroficzne zbiorniki z podwodnymi łąkami ramienic Charetea. In: J. Herbich (ed.). Wody słodkie i torfowiska. Poradniki ochrony siedlisk i gatunków Natura 2000 - podręcznik metodyczny, 2. Ministerstwo Środowiska, Warszawa: 4858.

Regulation of the Minister of Environment of October 9th, 2014, on the protection of plant species - Rozporządzenie Ministra Środowiska $z$ dnia 9 października 2014 r. w sprawie ochrony gatunkowej roślin. (2014). Dz.U. 2014 poz. 1409.

Urbaniak J., GąbKa M. (2014): Polish Charophytes. An illustrated guide to identification. Wydawnictwo Uniwersytetu Przyrodniczego we Wrocławiu, Wrocław.

URBANiAK J., GąBKa M., BlažEnČIĆ J. (2008): Nitella tenuissima, a rare Charophyte in Central and Southern Europe. Cryptogamie, Algologie 29, 2: 161-171.

VAN DEN BERG M.S. (1999): Charophyte colonization in shallow lakes: processes, ecological effects and implications for lake management. Typescript. $\mathrm{PhD}$ Thesis. Free University, Amsterdam. 


\section{APPENDIX 1}

\section{LIST OF CHAROPHYTE SPECIES RECORDED IN THE PUSZCZA ZIELONKA LANDSCAPE PARK. LOCALITIES AS IN FIGURE 1.}

Chara aspera - 1. Gackie Lake No. 4.

Chara contraria - 1. Gackie Lake No. 4; 2. Kamińsko Lake No. 18; 3. Pławno Lake No. 21; 4. peatland exploitation in Dziewicza Góra No. 35; 5. gravel pit in Owińska No. 34.

Chara filiformis - 1. Miejskie Lake No. 19.

Chara globularis -1 . peatland exploitation pond near Gackie Lake No. 3; 2. Gackie Lake No. 4; 3. Dobra Lake No. 11; 4. pond in the arboretum in Zielonka No. 14; 5. peatland exploitation pond in Zielonka No. 15; 6. Kamińsko Lake No. 18; 7. Pławno Lake No. 21; 8. Kociołek Lake No. 22; 9. Czarne Duże Lake No. 24; 10. Stęszewskie Lake No. 31; 11. Wronczyńskie Duże Lake No. 32, 12. pool near the "letnisko Zielona Polana" in Kołata No. 33; 13. gravel pit in Owińska No. 34.

Chara hispida - 1. pond near Borówie Lake No. 6; 2. peatland exploitation pond near Dzwonowskie Lake No. 10; 3. pond in Głębocko No. 12; 4. peatland exploitation pond in Zielonka No. 15; 5. Trojanka spring pool No. 16; 6. Pławno Lake No. 21; 7. Kociołek Lake No. 22; 8. Czarne Duże Lake No. 24, 9. Czarne Małe Lake No. 26; 10. Modre Lake No. 27; 11. Tuczno Lake No. 29; 12. waterhole near Owińska Struga No. 36.

Chara intermedia - 1. peatland exploitation pond near Sławica No. 1; 2. Gackie Lake No. 2; 3. peatland exploitation pond near Gackie Lake No. 3; 4. peatland exploitation pond near Borówie Lake No. 7; 5. Książe Lake No. 8; 6. Turostowskie Lake No. 13; 7. Karpnik Lake No. 17; 8. Kamińsko Lake No. 18; 9. Miejskie Lake No. 19; 10. Pławno Lake No. $21 ; 11$. Kociołek Lake No. 22; 12 . Czarne Duże Lake No. 24; 13. Czarne Małe Lake No. 26; 14. Modre Lake No. 27; 15. Stęszewskie Lake No.
31; 16. pool near the "letnisko Zielona Polana" in Kołata No. 33.

Chara polyacantha - 1. Kamińsko Lake No. 18; 2. Pławno Lake No. 21; 3. peatland exploitation in Dziewicza Góra No. 35.

Chara tenuispina - 1. peatland beetwen Czarne Duże and Czarne Małe lakes No. 15.

Chara tomentosa - 1. peatland exploitation pond near Sławica No. 1; 2. Garnek Lake No. 2; 3. Gackie Lake No. 4; 4. Borówie Lake No. 5; 5 . pond near Borówie Lake No. 6; 6. Książe Lake No. 8; 7. Dzwonowskie Lake No. 9; 8. Kamińsko Lake No. 18; 9. Miejskie Lake No. 19; 10. Pławno Lake No. 21; Kociołek Lake No. 22; 11. Czarne Duże Lake No. 24; 12. Czarne Małe Lake No. 26; 13. Modre Lake No. 27; 14. Kołatkowskie Lake No. 30; 15. Stęszewskie Lake No. 31; 16. Wronczyńskie Duże Lake No. 32.

Chara virgata - 1. peatland exploitation pond near Sławica No. 1; 2. Garnek Lake No. 2; 3. Książe Lake No. 8; 4 . peatland exploitation pond near Dzwonowskie Lake No. 10; 5. Dobra Lake No. 11; 6. Karpnik No. 17; 7. Kamińsko Lake no. 18; 8. Miejskie Lake No. 19; 9. peatland exploitation ponds near Pławno No. 20; 10. Pławno Lake No. 21; 11. Czarne Małe Lake No. 26; 12. Modre Lake No. 27; 13. Tuczno Lake No. 29; 14. Kołatkowskie Lake No. 30; 15. Stęszewskie Lake No. 31.

Chara vulgaris - 1 . peatland exploitation pond in Zielonka No. 15; 2. Czarne Duże Lake No. 24; 3. gravel pit in Owińska No. 36; 4. waterhole near Owińska Struga No. 36.

Nitella capillaris - 1. Pławno Lake No. 21.

Nitella gracilis - 1. pool near the Tuczno Lake No. 28. Nitella syncarpa - 1. Modre Lake No. 27.

Nitella tenuissima - 1. Modre Lake No. 27.

Nitellopsis obtusa - 1. Garnek Lake No. 2; 2. Gackie Lake No. 4; 3. Borówie Lake No. 5; 4 . Książe Lake No. 8; 5. Dzwonowskie Lake No. 9; 6. Dobra Lake No. 11; 7. Karpnik Lake No. 17; 8. Czarne Duże Lake No. 24; 9. Kołatkowskie Lake No. 30; 10. Stęszewskie Lake No. 31; 11. Wronczyńskie Duże Lake No. 32; 12. gravel pit in Owińska No. 34. 